\title{
Grammar Teaching Beliefs and Practices: The Case of a Communicative English Skills Teacher in DMU
}

\author{
Mengistu Anagaw \\ Debre Markos University
}

\begin{abstract}
The study intends to explore how the tensions, debates and beliefs about grammar teaching are adjudicated by a communicative English skills teacher to inform his practices. To that end, the researcher investigated an EFL teacher's beliefs and classroom practices' on the teaching of grammar in DMU. The data gathering instruments used were observation and semi structured interview meant to assess the way grammar is taught and uncover the underlying beliefs towards the teaching of grammar.

The teacher is assumes contextualizing grammar items and using situations is a good thing in learning grammar while he also believes explicit grammar instruction might be appropriate only in lower grades. Regarding elements /dimensions of grammar to be taught and techniques and activities to be used the teacher believes that he has to dwell on the harmonized materials surfacing lack of awareness about the semantic, syntactic and pragmatic trinities.

In the actual classroom, the teacher hardly created a context where their communicative needs necessitated the grammar structures. The teacher adopted PPP and situations and contexts were not created. The presentation stage took much time and effort followed by the practice, but no time for production resulting in absence of integration of skills. The teacher emphasized the structural aspect of grammar items more and syntactic and pragmatic aspects less going

The discrepancies between the beliefs and practices are significant though not enormous. Though the teacher believes in creating context for grammar teaching the observations didn't prove this. The essence of and principles of PPP is of little importance these days as proved in research. Moreover, the emphasis on form and use can't guarantee an effective grammar lesson. Based on these findings the researcher recommends further investigation of the issue encompassing students' views and larger samples.
\end{abstract}

DOI: $10.7176 /$ JLLL/59-01

Publication date: August $31^{\text {st }} 2019$

\section{INTRODUTION}

Traditionally, grammar teaching is viewed as the presentation and practice of grammatical structures. This involves any the use of different instructional techniques that draw learners' attention to some specific grammatical form in such a way that it helps them either to understand it meta linguistically and/or process it in comprehension and/or production so that they can internalize it. However, the issue of language teaching and the ways it should be approached as well as the techniques to be adopted has made the issue full of controversies.

One among the controversies is if grammar should be taught explicitly or not. Relating to this studies reported that instructed learners generally achieved higher levels of grammatical competence than naturalistic learners and showing that the acquisition processes of instructed and naturalistic learning were the same but that instructed learners progressed more rapidly and achieved higher levels of proficiency. Thus, some researchers concluded that teaching grammar was beneficial but that to be effective grammar had to be taught in a way that was compatible with the natural processes of acquisition (Long, 1988). Thus, issues has raised doubts on the relevance of assumptions of implicit teaching of grammar.

Another issue of controversy is on which grammar element to give primacy. Earlier works asserted that grammar is all about form, yet Larsen- Freeman (2014) rejects this on two grounds. The first argument is the goal of grammar teaching which is achieving a better fit between grammar and communication, it is not helpful to think of grammar as a discrete set of meaningless, decontextualized, static structures. The second is questions the purpose in thinking grammar solely as prescriptive rules about linguistic form, such as injunctions against splitting infinitives or ending sentences with prepositions. Stepping on this, Larsen Freeman (2014) underline that three dimensions must concern grammar teaching: structure or form, semantics or meaning, and the pragmatic conditions governing use.

While it is undisputable that teacher's belief play a significant role in their classroom practices the consequences of their belief would be of paramount implications where controversial issues like the teaching of grammar are at stake. For instance, Larsen- Freeman (2014) stipulated that

a grammar lesson should comprise, in addition to form, syntactic and pragmatic elements. Hence, a teachers' beliefs on what grammar is and how it should be delivered play a crucial role on how classroom practices take place. Therefore, understanding teachers' beliefs is essential to improve teaching practices and 
teacher education programs in general and the teaching of grammar in particular.

When it comes to universities in Ethiopia, wherein all students take communicative English skills course which incorporate grammar lessons on tenses, relative clauses, passive and conditional sentences, the effort is to raise students communicative competencies thereby making them ready to use the language. However, due to a number of factors the state of the art in the teaching of grammar is not so effective that the productive skills of graduating students even after three years of study has shortcomings as it can be learned from marking their research papers. Part of the problem might be caused by the teachers' belief about the teaching of grammar and their practices. Therefore, in this study, I want to examine the beliefs and actual practices on grammar teaching of an EFL teacher in DMU

Teachers' beliefs is said to be one of the factors which could affect the process of learning grammar. In Ethiopia, where grammar has been taught from primary schools to universities, even graduates are communicatively incompetent which manifests their grammatical incompetence. Thus, lack of communicative competence of students who graduate with good grades instigated the study to explore an EFL teachers' beliefs and classroom practices of teaching grammar. The study intends to explore how the tensions, debates and beliefs about grammar teaching are adjudicated by the teacher to inform his practices. Hence, in this study, the researcher investigated the case of an EFL teacher's beliefs and classroom practices' on the teaching of grammar in DMU.

The general objective of the study is to investigate an EFL teachers' beliefs and classroom practices' on the teaching of grammar in DMU. More specifically the study intends to:

1. Identify the teachers' beliefs about the way grammar should be taught.

2. Describe how the teacher practice the teaching of grammar.

3. Demonstrate the discrepancies between the stated beliefs and actual practices.

\section{Research Methodology}

In order to answer the research questions posed, the researcher employed a qualitative exploratory study. The case grammar teaching beliefs and practices of an EFL Communicative English skills instructor are investigated in details. The grammar teaching beliefs and practices of an English language instructor of DMU is the focus of the study. The study employed both available and purposive sampling techniques to choose the department and the research participants respectively.

The researcher used two data gathering instruments: observation and semi structured interview. The classroom observation was meant to assess the way the teacher taught his grammar lessons. Observations were made during lessons on the passive and conditional sentences. The main purpose of a post-lesson interview was to gather information about the teachers' beliefs towards the teaching of grammar in general. The interview was audio-recorded and then transcribed in full as well as coded which was used to explore the teachers' beliefs about the teaching of grammar.

The data obtained from both interview and observations were analyzed qualitatively and thematically. The unstructured interview were transcribed, sequenced and presented verbatim and analyzed thematically. Similarly, the observation data were transcribed and analyzed using narrative form. Data from both sources is presented together adopting a thematic crossover approach to ensure clarity and avoid redundancy.

\section{Results and Discussions}

In this section, the results obtained from classroom observation and interview are presented and discussed thoroughly.

\subsection{Teacher beliefs and practices on grammar teaching}

The first lesson observed was on the passive. The teacher set on the lesson by revisiting the notion of verbs in English. The teacher ensured students that verbs are classified in different ways of which the transitive intransitive classification is one. Further discussions on direct and indirect objects was also made. This must have helped students discern verb use in general and passive active construction in particular. According to Savignon (1991) this enables learners focus on grammar as it builds on previously mastered structures. The lesson on conditional sentences followed the same pattern. The teacher made a clear revision on the notion of conditionals and its definitions. However, the teacher hardly created a context where their communicative needs necessitated the structures. Relating to this, Harmer (1987) states that the best way to introduce the grammar lesson is to present the language item in a meaningful context. Hence, creating an authentic situation where the grammatical elements can be used would have contributed a lot. The presentation and practice activities predominantly reflect an emphasis on the structure. In other words the deductive approach of presentation, practice and production was sought.

During the interview the teacher reported that he has a good experience of learning and teaching grammar as a student and university lecturer later. In response to a question on his experience of learning and teaching 
English grammar the respondent acclaimed that:

Actually in lower grades I learned explicit grammar items. Do this one and don't do that items. When I come to my university experience, I have learned some grammar items through situation and conditions and I have developed some grammar items. Then I come to my teaching experience here, I teach grammar through situations and contexts actually. The module is already prepared and we have already identified those grammar items. So I pick those points in the module.

The implications of this is far reaching. One belief the teacher upheld as it can be inferred from this is that contextualizing grammar items and using situations is a good thing in learning grammar. The other belief held by the teacher is that explicit grammar instruction might be appropriate only in lower grades. In the classroom observations made, situations and contexts were not created during the lessons observed which might be due to tight schedule or because these are not provided in the module in such a way. Recent research findings relating to this stipulate that grammar tasks which emphasize consciousness-raising rather than practice appear to be an effective type of classroom activity. Nassaji and Fotos (2004) reports that the explicit grammatical instruction with communicative activities has its own advantages because after awareness of grammatical structures has been developed by formal instruction or some type of implicit focus-on-form treatment, many learners tend to notice the target structures in subsequent communicative input.

The second item relating to the first inquired the teacher if he thinks we should teach grammar or create conditions by which learners learn naturally. He responded:

In my opinion, teaching grammar through conditions through different contexts is very important. Right, just when I give students different conditions or contexts they can learn from those things. And they're very important even to remember. However, we have to make our students aware of those grammar points At last only creating Conditions is not enough I think. Therefore showing those grammar items isolated is very important.

The belief that teaching grammar items via contexts and situations i.e. implicitly has a wide support. Besides, the teacher strengthened this stance by asserting the need for explicit teaching of grammar items so that students will focus. This relates with the norm of the established trend (presentation, practice and production) and deviates from the integrative grammar teaching of Sysoyev (1999) in some respects. Ellis (2006) underlines that grammar teaching which is often viewed as entailing intensive instruction via the present-practice-produce (PPP) model of grammar teaching, assumes an intensive focus on specific grammatical structures. Conversely, as of Sysoyev (1999) the EEE (exploration, explanation \& expression) is considered as a way of combining form and meaning in teaching L2 grammar to ESL students that let students spend some time discussing and discovering grammatical patterns, listening to explanations and using new structures spontaneous in interaction, producing meaningful utterances respectively.

In the actual classroom, the teacher emphasized the structural aspect of grammar items more and syntactic and pragmatic aspects less going through the structure of the passive and the conditionals and writing forms on the blackboard. The lessons began with an explanation of the form and proceeded with provision of examples. For instance during the grammar lesson on the passive the teacher made an explicit discussion on verbs and their types as well as objects. Thence, an elaboration of the structure and uses the active and passive voices was made. The examples used reemphasized the structure i.e. sentences that can be changed and can't be changed in to the passive were provided. Some of the examples used were the following.

A. Hana cleaned the room.

B. Someone stole my pen.

C. She is dancing.

The examples, in addition to being precise for understanding, suit to show reasons for the use of the passive.

However, the time and variety of activities allotted for the practice and production of learned grammatical points has to be questioned. First extra time was used to present the grammar points. This might be worsened as the students were requested to sit and listen silently for a longer while making them passive. Once this was done, the teacher let students work in groups to practice the structure based on given task. The production step could have required a writing or speaking activity wherein students would demonstrate their success in an integrated skills lesson. In general the teacher is of the view that creating situations where students learn naturally should be supported by explicit teaching of rules.

Concerning the integration of grammar with other skills, though it was not observed in the actual lessons, the interviewed teacher asserted that:

Here we have two ideas actually. One is teaching grammar separately the other is teaching grammar in an integrated manner. When I say an integrated manner

this one is the best way I think.... when I teach grammar inside the classroom I

remember those things I tried to integrate other skills. For example when you teach speaking there is grammar when you teach writing there is grammar and other skills too. Grammar is very important with those skills. 
Hence, though the teacher's belief is that grammar lessons should be integrated with other skills the actual practices in the classroom went the other way. There are current research findings supporting the issue of presenting grammar integrated with other skills.

The teacher was also asked regarding the provision and appropriateness of feedback during grammar lessons. He acclaimed that he gives chances for students to make self-corrections. To put it verbatim the teacher reported:

When I teach these grammar points I have tried to form groups. Actually I'm not correcting students one by one. However, I have tried just to collect students or to come together anyways. And then ... to correct their errors \& to learn from their errors and to correct from their peers ... anyways I use it to correct my students' errors through group activities and the like.... Learning from their errors is very important.

During the grammar lessons observed, the teacher gave chances to make self-corrections and get peer feedback in group works. Similarly, Ur (1996) advises teachers to give feedback (oral or written) in a friendly way to help learners use the language for meaningful communication on the condition students fail to correct errors which distort meanings.

Then the teacher was asked about the elements of grammar and grammar teaching techniques and activities used in his classroom. In response to this, the teacher stated that:

Okay if I understood your question what do you teach inside class or when you have grammar lessons? We teach those grammar points that are clearly stated in the module. As you know the module is prepared based on the harmonized curriculum. However, when we teach these grammar items we have tried to add some other extra points regarding the activities regarding how to identify those grammar points and the like. As a teacher we add so many things.

The classroom observations revealed that the teacher gives primacy to form and use over meaning. For majority of the lesson, the teacher illustrated the form and the use of the passive and conditional sentences. The tasks given requested learners predominantly to practice form. However, Larsen- Freeman (2014) argues to incorporate structure or form, semantics or meaning, and the pragmatic conditions of use as important elements of a grammar lesson. Moreover, Nassaji and Fotos (2004) suggests that the main purpose of a grammar lesson is to help learners to use the language for communication, so EFL/ESL teachers are required to teach grammar and communication in combination.

Pertaining the grammar teaching techniques and activities, the teacher interviewed stated that he makes use of the activities provided in the harmonized module. During the observations the teacher adopted those activities using different techniques of delivery. For instance, once the lecture is completed, the students worked in groups to discuss and accomplish grammar activities.

\section{Conclusions}

This study investigated and compared the beliefs and actual instructional practices of an EFL instructor currently teaching the course communicative English skills in the department of English language and literature of Debre Markos University. The findings indicated that the EFL teacher is aware of his majority of his beliefs regarding grammar teaching as proved in his practices. In spite of this but from the interviews it could be deduced that their beliefs and actual practices which were checked through observations were almost similar. However, there was a discrepancy among their beliefs, practices and what the contemporary literatures suggest on the teaching of English grammar. Accordingly the following specific conclusions are drawn.

\section{The teacher holds the following beliefs:}

The teacher assumes that contextualizing grammar items and using situations is a good thing in learning grammar while he believes explicit grammar instruction might be appropriate only in lower grades.

The teacher believes explicit teaching should be done to solicit and stabilize already accomplished lesson favoring PPP and rejecting EEE.

Concerning integration of skills, the teachers' belief is that grammar lessons should be integrated with other skills.

Regarding elements /dimensions of grammar to be taught and techniques and activities to be used the teacher believes that he has to dwell on the harmonized materials.

2. The practices are concomitant with the beliefs stated above and comprise:

The teacher hardly created a context where their communicative needs necessitated the grammar structures.

The teacher adopted PPP and situations and contexts were not created during the lessons observed which might be due to tight schedule or because these are not provided in the module in such a way. The presentation stage took much time and effort followed by the practice, but no time for production resulting in absence of integration of skills. 
The teacher emphasized the structural aspect of grammar items more and syntactic and pragmatic aspects less going through the structure of the passive and the conditionals and writing forms on the blackboard. The lessons began with an explanation of the form and proceeded with provision of examples.

The teacher supports and appreciates students to make self-corrections. The teacher uses active learning methods.

The classroom observations revealed that the teacher gives primacy to form and to a limited extent use over meaning.

The discrepancies between the beliefs and practices are significant though not enormous.

In this regard, though the teacher believes in creating context for grammar teaching the observations didn't prove this. The essence of and principles of PPP is of little importance this days as proved in research. Moreover, the emphasis on form and use can't guarantee an effective grammar lesson.

\section{References}

Celce- Murcia, M. (1991). 'Grammar Pedagogy in Second and Foreign Language Teaching'.TESOL Quarterly, $25(3) 459-478$.

Cook, V. (2001). Second Language Learning and Language Teaching. London: Oxford University Press.

Doughty, C., and J. Williams, eds. 1998. Focus on Form in Classroom Second Language Acquisition. Cambridge: Cambridge University Press.

Ellis, R. (2001). Introduction: Investigating Form - Focused instruction. Language learning, 51(1), 1-46.

Ellis, R. (2002). Grammar teaching - practice or consciousness-raising? In J. C. Richards, \& W. A. Renandya (Eds.), Methodology in language teaching: An anthology of current practice (pp. 167-74). Cambridge: Cambridge University Press.

Ellis, R. (2003). Task-based language learning and teaching. Oxford: Oxford University Press.

Ellis, R. (2006). Current Issues in the Teaching of Grammar: An SLA Perspective. TESOL Quarterly Vol. 40 (1) 83-107

Harmar, J. (1987). Teaching and Learning Grammar: London: Longman.

Larsen-Freeman, D. (2001). 'Teaching Grammar.' In Celce- Murcia, M (ed.) Teaching English as a Second or Foreign Language. United States of America: Heinle and Heinle.

Larsen-Freeman, Diane. (2014). Teaching grammar. Teaching English as a second or foreign language. 279-296. Larsen-Freeman, D. (2003). Teaching language: From grammar to Grammaring. Heinle \& Heinle Pub

Long, M. H. (2000). Focus on form in task-based language teaching. Language policy and pedagogy: Essays in honor of A. Ronald Walton, 179-192.

Nassaji, H. \& Fotos, S. (2004). Current developments in research on the teaching of grammar. Annual Review of Applied Linguistics, 24, 126-14

Savignon, S. J. (1991). Communicative language teaching: State of the art. TESOL quarterly, 25(2), 261-278.

Spada, N. \&. Lightbown P. M., (2008). Form-focused instruction: Isolated or integrated? TESOL Quarterly 42 , 181-207.

Syosoyev, P. (1999): Integrative L2 to Grammar Teahing: Exploration, Explanation.

Expression: The Internet TESL Journal

Ur, P. (1988). Grammar Practice Activities. Cambridge: Cambridge University Press.

Uysal HH (2010). Teacher beliefs and practices of grammar teaching: focusing on meaning, form, or forms? South African Journal of Education; 2014; 34(1) 1-1 